\title{
Marta Petelewicz"
}

\section{JAKOŚĆ ŻYCIA ŁÓDZKICH SZÓSTOKLASISTÓW W PERSPEKTYWIE PRZESTRZENNEJ}

\begin{abstract}
Abstrakt. Łódź jest miastem silnie zróżnicowanym przestrzennie zarówno w kontekście fizycznym, jak i społecznym. Zróżnicowanie poziomu jakości życia dotyczy również najmłodszych mieszkańców. Celem artykułu jest przedstawienie zależności pomiędzy jakością życia respondentów a statusem okolicy, w której mieszkają. Badania empiryczne stanowiące podstawę analiz przeprowadzone zostały techniką ankiety audytoryjnej wśród szóstoklasistów uczęszczających do szkół podstawowych o najwyższym i najniższym wskaźniku uczniów dożywianych. Analiza wymiarów jakości życia przeprowadzona została w oparciu o koncepcję having, loving, being E. Allardta, ponadto szczególną uwagę poświęcono ocenie okolicy zamieszkania. Wykazano, że wymiary having i being oraz stosunek do okolicy zamieszkania wiążą się z zamieszkiwaniem w okolicy o określonym statusie. Zgodnie z aplikacyjną funkcją badań jakości życia informacje na temat dobrostanu najmłodszych mieszkańców powinny zostać uwzględnione przy projektowaniu strategii i ewaluacji działań podejmowanych w ramach polityki miejskiej.
\end{abstract}

Słowa kluczowe: jakość życia, dzieciństwo, zróżnicowanie przestrzenne miasta.

\section{Wstęp}

Analizy jakości życia społeczeństwa jako całości i wyróżnionych w jego ramach kategorii na stałe weszły do repertuaru analiz społecznych w wielu krajach (szczególnie Wielka Brytania, kraje Skandynawskie, USA, Kanada). Służą monitorowaniu sytuacji na różnych polach, budowaniu strategii działania w ramach rozwiązań politycznych, szczególnie w zakresie polityki społecznej, a także analizie skutków społecznych wprowadzanych rozwiązań oraz nieplanowanych zjawisk, jak np. kryzys ekonomiczny. Wzrost zainteresowania prowadzeniem i praktycznym wykorzystaniem wyników badań QOL (quality of life) na poziomie lokalnym jest jednym z głównych trendów w rozwoju badań opartych na

* Katedra Socjologii Struktur i Zmian Społecznych, Instytut Socjologii, Wydział Ekonomiczno-Socjologiczny, Uniwersytet Łódzki, ul. Rewolucji 1905 r. nr 41/43, 90-214 Łódź; e-mail: petelewicz@uni.lodz.pl 
wskaźnikach społecznych. Projekty pomiaru wskaźników jakości życia mieszkańców w środowisku lokalnym (community studies) to w Polsce wciąż jeszcze rzadko podejmowane przedsięwzięcia (R o k i c k a (red.) 2013). Jednakże w krajach, w których demokracja lokalna i różne formy samorządności mają dłuższą tradycję, systematyczne monitorowanie różnych aspektów życia w mieście trwale wpisało się w repertuar działań władz lokalnych. Służą monitorowaniu sytuacji, śledzeniu zmian, stają się podstawą tworzenia strategii, a także ewaluacji wprowadzanych rozwiązań. W latach 90 . XX w. zaczęto dostrzegać konieczność wyróżnienia specyficznych kategorii, m.in. ze względu na wiek, w tym szczególnie osób starszych oraz dzieci i młodzieży, i dostosowania do ich specyfiki koncepcji jakości życia, narzędzi pomiarowych oraz projektów analiz i sposobów ich wykorzystania (N o 11 2002).

W ramach socjologii w Polsce nie prowadzono dotychczas badań jakości życia dzieci na szerszą skalę, nie spotkałam się z analizami dobrostanu najmłodszych mieszkańców na poziomie lokalnym. Szczególnie potrzebne są diagnozy sytuacji w obszarach dotkniętych problemami społecznymi. Jak wskazują badania i analizy, Łódź jest miastem doświadczającym licznych problemów społecznych i ekonomicznych (Krajowy Raport o Rozwoju Społecznym 2012). Badania środowisk spauperyzowanych prowadzone przez zespół socjologów (skupionych w łódzkiej szkole badań nad biedą i pomocą społeczną) prowadzone od lat 90 . XX w. wskazują na zjawiska wykluczenia społecznego, utrwalenie zróżnicowania przestrzennego miasta, międzypokoleniową transmisję nierówności społecznych (Warzywoda-Kruszyńska (red.) 19982001 ,Warzywo da-Kruszyń ska, J a n kow s ki 2010). Procesy te nie pozostają bez wpływu na najmłodszych łodzian. Mamy do czynienia z gettoizacją i juwenilizacją biedy. Analizy ujawniają upośledzoną pozycję dzieci wychowujących się w środowiskach defaworyzowanych, a także wskazują na zjawisko dziedziczenia statusu społeczno-ekonomicznego (Warzywoda-Kruszyńska 1999; Warzywoda-Kruszyńska, P e te le wi c z 2010). Już od wielu lat, od kiedy badania prowadzone przez prof. Warzywodę-Kruszyńską unaoczniły skalę zjawiska, używa się sformułowania „łódzka bieda ma twarz dziecka”. Jak pisze W. Warzywoda-Kruszyńska: „ofiarami i «przenosicielami» biedy do następnej fazy życia własnego oraz do następnego pokolenia są dzieci, wychowujące się w dysfunkcyjnych rodzinach ulokowanych w zdegradowanych fizycznie częściach miasta” (2009: 15). Zubożałe sąsiedztwa charakteryzuje nieremontowana od lat, zniszczona zabudowa, o najniższym poziomie wyposażenia w media wśród największych miast w Polsce. Wrażenie zaniedbania i upośledzenia wyostrza się przez procesy gentryfikacji, rewitalizację wybranych obszarów, które wyraźnie kontrastują z sąsiadującymi budynkami. 


\section{Empiryczne podstawy analiz}

W obliczu wspomnianych problemów społecznych, zwłaszcza ubóstwa i wykluczenia, które w ponadprzeciętny sposób dotykają dzieci i młodzież, ograniczając możliwości potencjalnego rozwoju i szanse życiowe, a zarazem przestrzennego zróżnicowania skali i zakresu problemów, wydaje się, że powiązanie analizy jakości życia dzieci z perspektywą przestrzenną jest szczególnie użyteczne w kontekście pogłębionej analizy sytuacji życiowej najmłodszych łodzian. Zaproponowane podejście pozwala udzielić odpowiedzi na kluczowe pytania: czy jakość życia najmłodszych mieszkańców miasta jest zróżnicowana przestrzennie? Jeśli tak, to jakich sfer funkcjonowania dotyczy? Postaram się udzielić odpowiedzi na nie w oparciu o analizę danych zgromadzonych w ramach projektu "WZLOT” - Wzmocnić szanse i osłabić transmisję biedy wśród mieszkańców miast województwa łódzkiego ${ }^{1}$. W ramach komponentu diagnostycznego przeprowadzono badania specyficznych grup ,zagrożonych w sposób szczególny ubóstwem i wykluczeniem społecznym w cyklu życia oraz w międzypokoleniowym przekazie" (Warzywoda-Kruszyńska, Golczyńska-Grondas 2010:16.) Jedną z nich byli uczniowie ostatniej klasy szkół podstawowych ${ }^{2}$ zamieszkujący obszary określone jako enklawy dziecięcej biedy. W pierwszym kroku podjęto próbę charakterystyki szkół ze względu na status ekonomiczny uczniów - odtworzono udział dzieci pochodzących z rodzin o niskim statusie ekonomicznym w łódzkich szkołach podstawowych. Za wskaźnik trudnej sytuacji ekonomicznej rodziny uznano otrzymywanie przez dziecko wsparcia w formie darmowych obiadów ${ }^{3}$. Dożywianie ${ }^{4}$ w postaci darmowych obiadów jest jedyną materialną formą

${ }^{1}$ Projekt realizowany był w latach 2007-2010 przez Katedrę Socjologii Stosowanej UŁ we współpracy z Instytutem Inicjatyw Społecznych. Koordynatorem projektu była prof. dr hab. Wielisława Warzywoda-Kruszyńska. Współfinansowany był przez Unię Europejską ze środków Europejskiego Funduszu Społecznego. Projekt składał się z 3 komponentów: diagnostycznego, dydaktycznego oraz promocyjno-informacyjnego.

${ }^{2}$ Zdecydowano, że badaniami objęci zostaną szóstoklasiści ze względu na poziom rozwoju poznawczego, a także odpowiednie kompetencje umożliwiające samodzielne wypełnienie kwestionariusza. $Z$ drugiej strony istotne było, aby badanie zrealizowane zostało z uczniami szkół podstawowych, w których obowiązuje rejonizacja, miało to kluczowe znaczenie dla analiz o charakterze przestrzennym.

${ }^{3}$ Metodologia stworzona została na seminarium magisterskim prowadzonym przez prof. W. Warzywodę-Kruszyńską w 2005 r., na podstawie zebranych ówcześnie danych powstały trzy niepublikowane prace magisterskie.

${ }^{4} \mathrm{Na}$ mocy Ustawy o ustanowieniu programu wieloletniego „Pomoc państwa w zakresie dożywiania” z dnia 29.12.2005 r. podjęto działania, których celem jest zapewnienie co najmniej jednego ciepłego posiłku dziennie dla ludności potrzebującej, w szczególności dzieciom i młodzieży oraz osobom starszym i samotnym. W 2007 r. 1,7 mln dzieci i młodzieży objętych zostało programem, w tym ponad 600 tys. na wsi. Dla dzieci i młodzieży pomoc udzielana jest w formie ciepłego posiłku w szkole, przedszkolu lub żłobku. W przypadku gdy szkoła nie posiada warunków do wydawania lub przygotowywania posiłków, kierownik ośrodka pomocy społecznej we współpracy 
wsparcia, którą ubogie dzieci otrzymują bezpośrednio. Formy wsparcia w postaci na przykład zasiłku rodzinnego i dodatków do niego przyznawane są „na dzieci”, ale odbiorca jest rodzic. O przyznaniu pomocy w formie dofinansowania obiadów decyduje kryterium dochodowe. W przypadku przyznawania bezpłatnych obiadów wynosi ono $150 \%$ kryterium dochodowego z Ustawy o pomocy społecznej, czyli 526,5 zł . Warto wspomnieć, że minimum socjalne dla czteroosobowej rodziny, wyliczone w grudniu 2007 r. przez Instytut Spraw Publicznych wynosiło 656,1 zł na osobę (K u r o w s ki 2008).

Na podstawie danych uzyskanych z Miejskiego Ośrodka Pomocy Społecznej (liczba dzieci dożywianych w poszczególnych szkołach) oraz Kuratorium Oświaty w Łodzi (liczba uczniów w poszczególnych szkołach) wyliczony został udział dzieci dożywianych we wszystkich szkołach podstawowych w mieście. Pierwszy etap badań przeprowadzony został w szkołach o najwyższym odsetku uczniów dożywianych, drugi - w szkołach o najniższym odsetku uczniów dożywianych (Warzywoda-Kruszyńska, Petelewicz 2010). Badania zrealizowane zostały techniką ankiety audytoryjnej w 19 szkołach podstawowych dobranych w sposób celowy $(\mathrm{N}=951)$.

Udział uczniów dożywianych, według danych z 2007 r., dla łódzkich szkół podstawowych przyjmował wartości od $1 \%$ do $52 \%$. Średnia wartość wskaźnika dla łódzkich szkół podstawowych, których było wówczas 85 , wynosi $13 \%$. Udział dzieci dożywianych dla 40 szkół podstawowych w Łodzi jest równy bądź wyższy od średniej (13\%), dla 10 szkół podstawowych jest równy bądź wyższy od podwojonej średniej (26\%). Na szczególną uwagę zasługuje fakt, że w sześciu szkołach odsetek dzieci dożywianych wynosi ponad 30\%, w trzech powyżej $40 \%$, a w jednej dożywianych jest ponad połowa uczniów.

Już sama analiza poziomu wskaźnika uczniów dożywianych w łódzkich szkołach ${ }^{6}$ unaocznia zróżnicowanie przestrzenne miasta w zakresie sytuacji materialnej uczniów, co jest szczególnie istotne w kontekście powiązanego z nim zróżnicowania edukacyjnego. Jak pisze M. Zahorska: „Jak się wydaje, czynnikiem decydującym o poziomie szkoły jest, w większym stopniu niż było to dotychczas, zamożność i aspiracje środowiska lokalnego" (2002: 304). Korelacja pomiędzy liczbą dzieci dożywianych w danej szkole a wynikami sprawdzianu szóstoklasistów ${ }^{7}$ mierzona współczynnikiem $r$ Pearsona wynosi $0,5(\mathrm{p}<0,001)$, a więc jest to silna zależność. Im więcej dzieci w danej szkole wychowuje się w rodzinach wspieranych przez MOPS, tym gorsze wyniki sprawdzianów osiagane są przez chodzących do niej uczniów. Analizie poddałam proste wskaźniki, nie brałam pod

z dyrektorem zobowiązany jest zapewnić możliwość spożywania posiłków poza szkołą, szkoła jest odpowiedzialna za zapewnienie dzieciom opieki w tym czasie.

${ }^{5} \mathrm{Gmina}$, która jest podmiotem odpowiedzialnym za realizację programu, może podjąć uchwałę o podwyższeniu kryterium dochodowego.

${ }^{6}$ Zgromadzonych na etapie przygotowania badań.

${ }^{7}$ Dane z $2007 \mathrm{r}$. 
uwagę innych czynników, które zapewne również wpływają na wyniki uczniów danej szkoły, jak: wielkość klas, infrastruktura, kwalifikacje nauczycieli etc. Uzyskane wnioski zgodne są z tezą T. Szkudlarka o parcelacji przestrzennej szkół, wywołanej przez ucieczkę elit z miejsc zaniedbanych, jak pisze: osoby z wyższym SES są ,,skłonne dowozić swoje dzieci do szkół uznanych za dobre, podczas gdy osoby o niższym statusie, często kierując się zasadą minimalizacji kłopotów, czyli posyłają dziecko do szkoły najbliższej miejscu zamieszkania. Bardzo często wynika to po prostu z biedy - dowożenie dziecka do szkoły w innej dzielnicy albo w innej miejscowości po prostu sporo kosztuje" (2007: 45). Przeprowadzając analizy przy pomocy wskaźnika, który służył do doboru próby - udział uczniów otrzymujących bezpłatne obiady w danej szkole podstawowej - dochodzimy do bardzo interesujących wniosków. Jest to o tyle ważne, że pozyskanie takich danych nie jest trudne, nie wymaga również narażenia uczniów czy rodziców na udzielanie informacji, często drażliwych, odnośnie do sytuacji w swoim gospodarstwie domowym. Umożliwia zaś uzyskanie obrazu sytuacji, który może stać się punktem wyjścia do dalszych diagnoz i działań.

\section{Charakterystyka terenu badań}

Pierwsza grupa szkół (najwyższy udział dzieci otrzymujących bezpłatne obiady) zlokalizowana jest w centrum miasta i przyległych obszarach. Dominuje w nich zabudowa substandardowa o niskim i bardzo niskim statusie społecznym oraz przedwojenna zabudowa czynszowa o niskim statusie społecznym (patrz: Marcińczak 2009). Cechuje je złe wyposażenie w media (CO, gaz, bieżąca woda [w drugim typie oprócz $\mathrm{CO}]$ ) oraz duży udział mieszkań komunalnych. W ramach charakterystyki społecznej zwraca uwagę wysoka stopa bezrobocia oraz przewaga osób zatrudnionych na stanowiskach niskopłatnych, do wykonywania nieskomplikowanych zajęć, „odnotowano najwyższy w mieście udział osób legitymujących się wykształceniem zawodowym i podstawowym" (ibidem: 100). Przestrzeń fizyczna tego obszaru charakteryzuje się zdegradowaną substancją mieszkaniową, dominują kamienice, w większości zniszczone i zaniedbane, chociaż znajdują się tu również silnie kontrastujące - odnowione, najczęściej ogrodzone budynki mieszkalne i apartamentowce. Okolica pozbawiona jest terenów rekreacyjnych, niewiele jest zieleni. Często najbliższe otoczenie dzieci stanowią tak zwane ,podwórka-studnie” otoczone ścianami kamienic, wybetonowane, pozbawione zieleni, ławek czy jakiejkolwiek innej infrastruktury dla dzieci. Najczęściej znajdują się tam jedynie kontenery na śmieci oraz parkujące samochody. Trzepak, najczęściej zardzewiały, stanowi miejsce spotkań i zabaw dzieci z okolicy. Nie dość, że brak jest tam infrastruktury sprzyjającej bezpiecznym dziecięcym zabawom, widoczne są próby ograniczenia aktywności najmłodszych. Na ścianach znajdują się tabliczki i napisy informujące o zakazie 
gry w piłkę. Najbliższe fizyczne otoczenie dzieci, poza które zwykle nie wychodzą, stanowi zdewastowana przestrzeń miejska. Przestrzeń w łódzkich enklawach dziecięcej biedy zbudowana jest $\mathrm{z}$ asfaltu i betonu, brak skwerów, parków, placów zabaw i boisk, nie odpowiada potrzebom dzieci, w niewielkim stopniu poddaje się przekształcaniu. Dzieci nie mają w niej najczęściej możliwości zaspokajania potrzeby tworzenia i kreacji swojego otoczenia, co często skutkuje aspołecznym zachowaniem. Brak możliwości tworzenia uaktywnia sferę oddziaływania ukierunkowaną na rozkład lub destrukcję. Proces destrukcji pozbawiany jest celowo przestępczego charakteru, ,jest on przejawem wrodzonego człowiekowi dążenia do oddziaływania na swe otoczenie poprzez: zabawę, chodzenie, przekształcanie, budowanie własnej, indywidualnej przestrzeni" (C u e ff 2006: 27). Jak wskazuje opracowanie praktyków na co dzień pracujących z „dziećmi na ulicy”, gdy przestrzeń fizyczna jest nieatrakcyjna, nieprzyjazna dla dzieci, zdecydowanie, a wręcz nadmiernie wzrasta znaczenie relacji rówieśniczych. Charakterystyka przestrzeni fizycznej, chociaż najłatwiej zauważalna, nie jest jedynym czynnikiem przesądzającym o sytuacji sąsiedztw nazywanych enklawami biedy. Co szczególnie istotne, w przypadku analizowanej kategorii wiekowej, ,jest środowiskiem wpływającym na możliwość rozwoju jednostek, poprzez występujące w nim zasoby, sposobności i ryzyka, a także ograniczającym szanse zmiany sytuacji życiowej mieszkańców" (Warzywoda-Kruszyńska, Go lczyńska-Grond as 201046. .)

Szkoły z drugiej grupy (określone w dalszej części artykułu skrótowo jako nieenklawy, co odnosi się do ich położenia poza obszarami określonymi jako enklawy dziecięcej biedy) mieszczą się w większości na osiedlach, gdzie dominują bloki z wielkiej płyty, budowane w latach 80 . XX w., dwie zlokalizowane są na obrzeżach miasta charakteryzujących się zabudową wolnostojącą. Ten typ okolicy zamieszkania określony został jako - wysoki status okolicy zamieszkania.

Dane stanowiące podstawę doboru próby oraz przeprowadzone obserwacje pozwalają na zakwalifikowanie uczniów określonych szkół podstawowych do dwóch kategorii miejsca zamieszkania. Nawiązując do postawionego we wstępie pytania, w dalszej części artykułu przedstawię wyniki analizy zależności pomiędzy kategorią okolicy zamieszkania a stosunkiem do najbliższej okolicy, która jest szczególnie istotna w perspektywie badań prowadzonych w społecznościach lokalnych, oraz analizę zróżnicowania jakości życia dzieci przeprowadzoną w oparciu o koncepcję having, loving, being Erika Allardta (1976).

\section{Stosunek do okolicy zamieszkania}

Na ocenę okolicy zamieszkania składać się może wiele aspektów, oprócz wyglądu budynków, charakterystyki zabudowy czy terenów zielonych, placów zabaw istotna jest również dostępność miejsc, gdzie dzieci mogą spędzać czas i rozwijać się, boisk, basenów czy instytucji kulturalnych: domów kultury, bibliotek, 
świetlic. Dla ustalenia tego, jak nastolatki postrzegają okolicę, w której mieszkają, czy dobrze się w niej czują, poproszono respondentów o dokonanie oceny, czy zamieszkiwanie „tutaj” daje im poczucie bezpieczeństwa, czy chcieliby się wyprowadzić, czy mogą tu spędzić ciekawie czas oraz czy mają tu dużo koleżanek i kolegów.

Na wykresie 1 pokazany jest udział respondentów, którzy negatywnie oceniają okolicę, wybrali odpowiedź „zdecydowanie nie” bądź „,raczej nie” na pytania: o poczucie bezpieczeństwa, możliwość ciekawego spędzenia czasu, posiadania koleżanek i kolegów; oraz zdecydowanie tak lub raczej tak na pytanie, czy chcieliby się stąd wyprowadzić, w podziale na respondentów zamieszkujących w okolicy o wysokim statusie (oznaczone jako nieenklawa) oraz zamieszkujących w okolicy o niskim statusie (oznaczone jako enklawa).

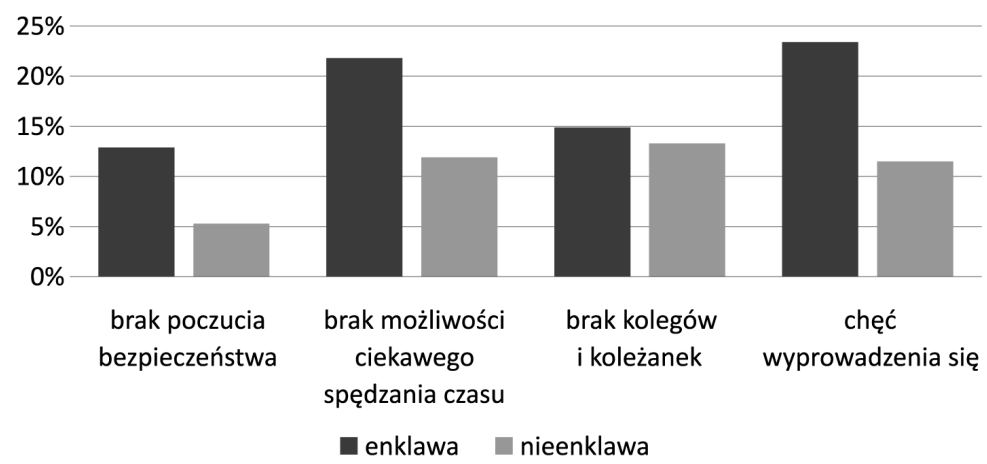

Wykres 1. Aspekty oceny okolicy zamieszkania w zależności od statusu miejsca zamieszkania

$$
\text { Źródło: opracowanie własne }
$$

Zdecydowana większość respondentów czuje się bezpiecznie w swojej okolicy, zwraca jednak uwagę dysproporcja pomiędzy kategoriami dzieci wyróżnionymi ze względu na status miejsca zamieszkania, bez mała trzy razy więcej dzieci z uboższych osiedli niż ich rówieśników mieszkających w lepiej sytuowanej okolicy nie ma poczucia bezpieczeństwa w swoim sąsiedztwie. Poczucie zagrożenia odbija się zdecydowanie niekorzystnie na funkcjonowaniu dzieci, ogranicza swobodę zabawy i zmniejsza aktywność. Negatywnie wpływa, w perspektywie indywidualnej, na rozwój dziecka, a w perspektywie społecznej, na budowę kapitału społecznego. Częściej niż co piąty respondent zamieszkujący w okolicy i niskim statusie stwierdzał, że w jego okolicy brak jest miejsc, gdzie można ciekawie spędzić czas, chociaż, paradoksalnie, właśnie w centrum miasta zlokalizowane są miejsca, które wydają się być atrakcyjne dla dzieci: kina, teatry, sale zabaw, ścianki wspinaczkowe itp. Wydaje się, że kryterium jest nie bliskość w przestrzeni, lecz realna dostępność. Co więcej, dziecko odnosi się do doświadczeń codziennych, 
a więc szczególnie istotne są obszary, gdzie może realizować swoją codzienną aktywność, w której nie potrzeba nakładów finansowych ani asysty dorosłych, istotne więc są place zabaw, boisko, tereny zielone, gdzie można pojeździć na rolkach czy rowerze, ewentualnie klub/świetlica. Co czwarty szóstoklasista z enklawy biedy i co dziesiąty z obszaru lepiej sytuowanego chciałby się przeprowadzić. Znaczna część dzieci nie czuje się komfortowo w miejscu, w którym mieszka, nie jest związana z najbliższą okolicą, a prawdopodobnie również z sąsiadami.

$\mathrm{Na}$ podstawie opisanych zmiennych stworzony został indeks oceny okolicy, w jego skład włączone zostały zmienne: poczucie bezpieczeństwa, ocena możliwości ciekawego spędzania czasu, chęć wyprowadzenia się. Współczynnik $\alpha$ Cronbacha dla tak stworzonej skali wynosi 0,69 , wskazując na właściwy poziom rzetelności skali. Wprowadzenie zmiennej: posiadanie kolegów i koleżanek w okolicy obniża poziom rzetelności skali, wskazując na fakt, że zabawa z kolegami i koleżankami z sąsiedztwa jest niezależna od ogólnej oceny okolicy zamieszkania.

Analiza testem t-Studenta dla prób niezależnych wykazała, że zamieszkiwanie w przestrzeni Łodzi o określonej charakterystyce wpływa na ocenę okolicy przez uczniów t $(889)=-6,44 ; \mathrm{p}<0,001$. Ogólna ocena wyrażona przez respondentów uczęszczających do szkół w obszarach określonych jako enklawy dziecięcej biedy $(\mathrm{M}=11,49, \mathrm{SD}=3,04)$ jest istotnie statystycznie niższa od oceny wyrażonej przez uczniów mieszkających na osiedlach oddalonych od centrum miasta $(\mathrm{M}=12,65, \mathrm{SD}=2,34)$. Wielkość efektu $(d$ Cohena $=0,4)$ wskazuje, że związek między analizowanymi zmiennymi jest średni. Uzyskane wyniki potwierdzają zróżnicowanie pomiędzy grupami wyróżnionymi ze względu na obszar zamieszkania w ocenie swojej okolicy.

\section{Analiza jakości życia w oparciu o koncepcję E. Allardta}

Koncepcja wskaźników badających 'dobrostan' społeczeństwa stworzona przez fińskiego badacza Erika Allardta jest wyraźnym nawiązaniem do teorii potrzeb. Pierwsze badania empiryczne oparte na jej założeniach - Comparative Scandinavian Survey zostały przeprowadzone w 1972 r. Geneza koncepcji i analiz Allardta związana jest $\mathrm{z}$ analizą funkcjonowania i próbą udoskonalania polityki społecznej w ramach skandynawskiego modelu welfare state. Pojęcie welfare (dobrobyt) ujmowane jest jako stan zakładający zaspokojenie potrzeb w społeczeństwie (A 11 ar d t 1976). Próbuje się go zmierzyć za pomocą złożonych systemów wskaźników społecznych. Allardt twierdzi, że obiektywne wskaźniki mówiące o zaspokojeniu potrzeb materialnych nie są wystarczające, aby wyrokować o tym, jak żyje się członkom danego społeczeństwa. Według autora konieczna jest wielowymiarowa analiza, dlatego też wprowadza dwa kluczowe rozróżnienia:

- dobrobyt i szczęście (welfare vs. happiness) - poziom dobrobytu jest definiowany przez stopień zaspokojenia potrzeb. Szczęście odnosi się do subiektywnych 
ocen i doświadczeń, do tego, w jakim stopniu ludzie czują się szczęśliwi, zadowoleni. Na poziomie operacyjnym znaczy to, że dobrobyt można szacować na podstawie dóbr, zachowań i stosunków społecznych, natomiast szczęście można mierzyć poprzez analizowanie opinii i odczuć (ibidem);

- poziom życia i jakość życia (level of living vs. quality of life) - poziom życia odnosi się do zasobów materialnych (nieosobowych), przy pomocy których ludzie mogą „rozporządzać” swoim życiem. Odnosi się do potrzeb, stopień zaspokojenia których jest definiowany przez zasoby materialne i nieosobowe. Jakość życia rozumiana jest jako satysfakcja z kontaktów międzyludzkich oraz samorealizacji, definiowana poprzez relacje do innych, społeczeństwa oraz samego siebie (ibidem).

Koncepcja E. Allardta pozwala na analizę funkcjonowania ludzi w różnych sferach życia i nie ogranicza się do badania materialnych warunków życia, ale obejmuje jeszcze dwa inne wymiary - pierwszy związany z życiem społecznym, sferą stosunków międzyludzkich (rodzina, przyjaciele, społeczność lokalna), określanym jako Loving - kochać (M i s i u n a 1979), oraz drugi - związany z dobrym samopoczuciem psychicznym jednostki, zadowoleniem z siebie, swojego otoczenia i społeczeństwa, w którym żyje, poczuciem własnej wartości, samorealizacji - Being - być. W późniejszych obszarach autor wyróżnił jeszcze sferę zdrowia. Według M. Nussbaum i A. Sena (2006) przewaga ujęcia Allardta polega właśnie na wyjściu poza analizowanie zamożności czy użytkowanie zasobów. Identyfikuje ono wiele aspektów jakości życia, które nie dają się zredukować do wymiaru materialnych warunków życia.

Koncepcja E. Allardta pozostaje do dziś jedną z kluczowych koncepcji w analizach jakości życia. Wielokrotnie wykorzystywano ją do analizowania stanu społeczeństw, dostosowując i modyfikując ją do specyfiki terenu badań czy kategorii społecznej (D e 1 h e y 2004). Nie spotkałam jednak propozycji zastosowania jej do badania dzieci i młodzieży, konieczne było więc dostosowanie wypracowanych pojęć do specyfiki respondentów znajdujących się w określonym etapie cyklu życia.

Kluczową kwestią pojawiającą się w koncepcji Allardta $(1973,1976)$ jest pytanie, czy występuje zależność pomiędzy jakością życia w różnych wymiarach a cechami społeczno-demograficznymi. Jak zostało to ujęte przez autora „czy jakość życia zależy od tego, kim się jest?” Odpowiadając na nie, autor koncepcji odnosi się do idei sprawiedliwości społecznej, która wyklucza taką zależność. Na potrzeby prowadzonych analiz może zostać przeformułowane: czy jakość życia związana jest $\mathrm{z}$ tym, gdzie mieszka dziecko?

Indeksy ${ }^{8}$ : having, loving, being i zdrowie stworzone zostały w oparciu o mierniki opracowane na podstawie zebranego materiału empirycznego:

- Na wymiar having składają się: warunki materialne rodziny, w tym warunki mieszkaniowe oraz warunki materialne stworzone dziecku.

- Na wymiar loving: relacje rówieśnicze i rodzinne.

${ }^{8}$ Indeksy zostały stworzone w oparciu o analizę czynnikową lub analizę rzetelności. 
- Na wymiar being: funkcjonowanie w szkole (będące odpowiednikiem kategorii kariery zawodowej z badań dorosłych).

- Na wymiar zdrowie: zachowania prozdrowotne i antyzdrowotne, doświadczane dolegliwości, choroby przewlekłe.

Po statystycznym opracowaniu indeksów oraz standaryzacji wyliczona została średnia wartość dla obydwu wyróżnionych ze względu na miejsce zamieszkania kategorii. Wizualizacja zależności pomiędzy wymiarami jakości życia (średnie wartości indeksów) na podstawie koncepcji E. Allardta a statusem okolicy zamieszkania znajduje się na wykresie 2 .

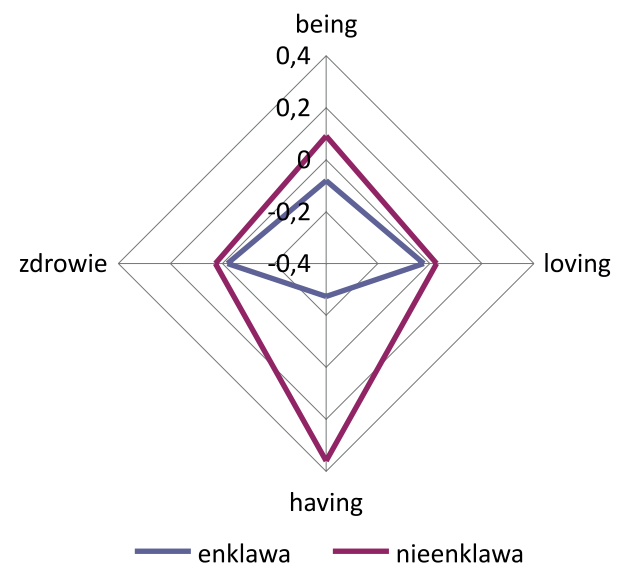

Wykres 2. Zależności pomiędzy wymiarami jakości życia (średnie wartości indeksów) na podstawie koncepcji E. Allardta a statusem okolicy zamieszkania

Źr ódło: opracowanie własne

Analiza wykresu unaocznia obszary największych dysproporcji. Zdecydowanie najsilniej zróżnicowany jest obszar warunków materialnych życia dziecka. Analiza testem t-Studenta dla prób niezależnych wykazała, że istnieje zależność pomiędzy statusem okolicy zamieszkania a sferą warunków materialnych $\mathrm{t}(949)=-11,926, \mathrm{p}<0,001$. Dzieci mieszkające poza enklawami mają istotnie statystycznie wyższy poziom warunków życia, wielkość efektu $(d$ Cohena $=0,78)$ wskazuje na silny związek pomiędzy statusem obszaru zamieszkania i wymiarem having. Gorsze warunki mieszkaniowe, znaczny odsetek dzieci, które nie mają podstawowych dóbr: jak własne biurko czy łóżko, brak możliwości wyjazdu na wakacje, uboższe wyposażenie gospodarstwa domowego wpływają zarówno na codzienne funkcjonowanie - doświadczanie dzieciństwa, jak i ograniczają możliwości rozwoju. Dzieci w okresie wczesnej adolescencji zaczynają zdawać sobie sprawę ze swojej gorszej sytuacji ekonomicznej. Rówieśnicy odgrywają coraz bardziej istotną rolę, co nieuchronnie wiąże się ze społecznymi porównaniami. Co więcej, często posiadanie określonych gadżetów, ubrań czy środków na wspólne 
wyjścia i aktywności stanowi ważny czynnik określający miejsce w hierarchii grupowej. Istotna statystycznie zależność występuje również pomiędzy sferą samorealizacji (being) a kategorią sąsiedztwa t $(949)=-3,447, \mathrm{p}=0,001$, wielkość efektu $(d$ Cohena $=0,22)$ wskazuje na niezbyt silną zależność. Dzieci mieszkające w okolicy o niskim statusie gorzej radzą sobie z funkcjonowaniem w szkole, dotyczy to nie tylko wyników, ale także samopoczucia, radzenia sobie z regułami, uczestnictwa w zajęciach pozalekcyjnych. Pogłębione analizy pokazują również niższą niż u lepiej sytuowanych rówieśników samoocenę oraz niższy poziom ogólnej oceny życia. Jakość życia w wymiarze relacji społecznych i zdrowia nie jest zróżnicowana ze względu na miejsce zamieszkania. Bardziej szczegółowe analizy z podziałem na relacje rówieśnicze i rodzinne czy różne aspekty związane ze stanem zdrowia i zachowaniami zdrowotnymi również nie ujawniają istotnego statystycznie zróżnicowania pomiędzy uczniami ze względu na status okolicy zamieszkania.

\section{Podsumowanie}

Badania jakości życia mieszkańców powinny stanowić ważne narzędzie w ramach polityki miejskiej zarówno na etapie diagnozy, jak i ewaluacji podejmowanych działań. Dotyczy to również najmłodszych mieszkańców, ważne jest upodmiotowienie, dostrzeżenie ich jako obywateli miasta „tu i teraz”, postrzeganie jako grupy, do której rzetelnie zdiagnozowanych potrzeb należy dostosować działania w ramach polityki miejskiej. Egzemplifikacją realizacji pogłębionych badań jakości życia dzieci w mieście oraz, co szczególnie warte podkreślenia, wykorzystania ich w projektowaniu rozwiązań są analizy prowadzone w Londynie. The State of London's Children Report jest przykładem, jak systematyczne analizy jakości życia dzieci mogą mieć bezpośredni wpływ na podejmowane działania i planowanie $\mathrm{w}$ różnych okresach w dużym mieście. Monitorowanie i raportowanie pełni kluczową rolę w rozwoju polityki miejskiej i poprawie jakości życia dzieci. Raport z badań stał się jednym z podstawowych źródeł przy tworzeniu strategii „Making London Better for All Children and Young People”, kolejne badanie stanowiło zaś próbę oceny efektów podjętych działań (H o o d 2007). Szczególnie istotne jest zwrócenie uwagi na dzieci jako kategorię mieszkańców, którym należy się odrębna, skrojona do gruntownie przeanalizowanych problemów i potrzeb strategia działania. Co więcej, najmłodsi zostali potraktowani podmiotowo, jako pełnoprawni informatorzy o swojej sytuacji, których głos obok tradycyjnych, „dorosłych” źródeł wiedzy o funkcjonowaniu najmłodszych został uwzględniony.

Podsumowując, respondenci mieszkający w okolicy o niskim statusie zdecydowanie gorzej czują się w swoim najbliższym sąsiedztwie, wskazują na brak możliwości ciekawego spędzania czasu, częściej doświadczają braku poczucia bezpieczeństwa. Bez mała co czwarty ankietowany uczeń chciałby się 
przeprowadzić. Co więcej, żyją w gorszych warunkach materialnych, zapewne mają mniejszą możliwość skorzystania z płatnej oferty rozrywkowej, kulturalnej i sportowej, mimo że instytucje, w których jest dostępna, zlokalizowane są w pobliżu. Mieszkania są gorzej wyposażone, dzieci nie mają do dyspozycji podstawowych sprzętów, oprócz tego mają mniejszą możliwość poznawania innych miejsc, o czym świadczy niższa częstotliwość wyjazdów. Zmagają się również z większymi trudnościami w szkole, mają obniżoną samoocenę oraz gorzej oceniają swoje życie. Z drugiej strony badania pokazują także mocne strony, np. relacje społeczne, które mogą stać się podstawą projektowania działań pomocowych.

W przestrzeni miasta wskazać można obszary, w których najmłodsi mieszkańcy doświadczają niższej jakości życia w określonych dziedzinach. Kumulacja problemów, deprywacji w domu, okolicy zamieszkania, szkole odbija się na codziennym funkcjonowaniu - doświadczaniu dzieciństwa, stwarza również ryzyko obniżonych szans życiowych, transmisji biedy i wykluczenia społecznego. Aby możliwe było przeciwdziałanie negatywnym skutkom niskiej jakości życia w dzieciństwie, zarówno w teraźniejszości, jak i w przyszłości, należy podjąć systemowe działania, zintensyfikowane w obszarach kumulacji problemów społecznych. Pierwszym krokiem powinna być pogłębiona, szeroko zakrojona diagnoza sytuacji najmłodszych łodzian, najlepiej przeprowadzana systematycznie, wzorując się na dobrych praktykach z innych miast. Następnie konieczne są skrojone na miarę, kompleksowe działania, inwestycja w najmłodszych mieszkańców - w dosłownie i w przenośni rozumianą przestrzeń aktywności i rozwoju - jest jedynym sposobem przerwania błędnego koła dziedziczenia problemów społecznych i „odczarowania” rejonów miasta cieszących się złą sławą.

\section{Bibliografia}

A 11 a rd t E. (1973), A welfare model for selecting indicators of national development, "Policy Sciences" 4.

A 11 a r d t E. (1976), Dimensions of welfare in a Comparative Scandinavian Study, „Acta Sociologica", Vol. 19/3.

C u e ff D. (2006), Dziecko na ulicy: zwalczanie przemocy wobec dzieci ulicy : przewodnik metodologiczny dla pedagogów ulicy : metody pracy w środowisku otwartym : europejski projekt DAPHNE.

D e $1 \mathrm{~h}$ e y J. (2004), Life satisfaction in an enlarged Europe, European Foundation for the Improvement of Living and Working Conditions, Luxembourg, Office for Official Publications of the European Communities.

H o o d S. (2007), Reporting on Children's Well-being, The State of London's Children Reports, Kluwer Academic Publishers, "Social Indicators Research", Vol. 80, s. 1249-1264.

Krajowy Raport o Rozwoju Społecznym 2012. Rozwój regionalny i lokalny. Biuro Projektowe UNDP w Polsce, www.ewaluacja.gov.pl/.../raport_undp_2012_lhdi_20420123.pdf

M i s i u n a M. (1979), Jakość życia - geneza i interpretacje pojęcia w krajach cywilizacji zachodniej, „Przegląd Socjologiczny”, t. XXXI/I. 
M a r c i ń c z a k Sz. (2009), Przemiany struktury społeczno-przestrzennej Łodzi w latach 19882005, Wydawnictwo Uniwersytetu Łódzkiego, Łódź.

N o 11 H. (2002), Social indicators and quality of life research, background, achievements and current trends, [w:] N. G e n o v (red.), Advances in sociological knowledge, Paris, ISSC.

R o k i c k a E. (red.) (2013), Jakość życia mieszkańców Łodzi i jej przestrzenne zróżnicowanie, Wydawnictwo Uniwersytetu Łódzkiego, Łódź.

S e n A. (2006), Capabilities and wellbeing, [w:] A. S e n, M. N u s s b a u m (red.), The quality of life, Calrendon Press, Oxford.

S z k u d l a r e k T. (2007), Edukacja i konstruowanie społecznych nierówności, [w:] J. K l e b a $\mathrm{n}$ i u k (red.), Fenomen nierówności społecznych, ENETEIA.

W a r z y w o d a-K r u s z y ń s k a W. (1 99 9 Xwestia ubóstwa dzieci (na przykładzie Łodzi), „Problemy Polityki Społecznej”, nr 1.

W a r z y w o d a-K r u s z y ń s k a W. (red.) (2001), (Żyć) Na marginesie wielkiego miasta, Wydawnictwo Uniwersytetu Łódzkiego, Łódź.

W a r z y w o d a-K r u s z y ń s k a W. (2 001 \jawisko biedy dzieci a zagrożenie wykluczeniem spotecznym w przyszłości. Mapa biedy - rozmieszczenie i zakres biedy wśród dzieci na terenie województwa łódzkiego, www.brpd.gov.pl/badaniabiedy.html [dostęp 17.01.2008].

W a r z y w o d a-K r u s z y ń s k a W. (2 003 Przeciwdziałanie międzypokoleniowej transmisji biedy-proponowanym celem rozwoju społecznego Polski, [w:] Polska dla dzieci. Ogólnopolski szczyt w sprawach dzieci. Materiaty i dokumenty, Rzecznik Praw Dziecka, Warszawa.

W a r z y w o d a-K r u s z y ń s k a W. (2 009 Bieda dzieci $w$ środowisku wielkomiejskim. Na przykładzie Łodzi, „Polityka Społeczna”, nr 9.

Wa r z y w o d a-K r u s z y ń s k a W., G o l c z y ń s k a-Grondas A. (2 010 Wzmocnić szanse i osłabić transmisje biedy wśród mieszkańców miast województwa tódzkiego, Wydawnictwo Biblioteka, Łódź.

W a r z y w o d a-K r u s z y ń s k a W. ,J a n k o w s k i B. (2 010 Mieszkańcy enklaw biedy po 10 latach, Wydawnictwo Biblioteka, Łódź.

Wa r z y w o d a-K r u s z y ń s k a W. ,P e t e 1 e w i c z M. (2 010 Bieda w dzieciństwie jako zagrożenie bieda i wykluczeniem społecznym, Wydawnictwo Biblioteka, Łódź.

$\mathrm{Z}$ a h o r s k a M. (2002), Szkoła: między państwem, społeczeństwem a rynkiem, Wydawnictwo Akademickie „Żak”, Warszawa.

\section{Marta Petelewicz}

\section{THE CASE OF THE 6TH GRADERS LIVING IN LODZ}

Summary. Sociological research show severe social problems and high level inequalities in Łódź. The disparity in the quality of life concerns also the youngest residents. The analyzes are based on the empirical studies that were conducted among the sixth-graders attending elementary schools with the highest and the lowest rate of students getting free meals. Analysis of the dimensions of the quality of life was carried out using the concept of having, loving, being introduced by E. Allardt, moreover, particular attention was paid to the perception and evaluation of the neighborhood. The dimensions of having and being, and the assessment of the neighbourhood is related with the status of the area residence. The knowledge concerning well-being of the youngest residents and its spatial diversity should be taken into account in policy-making process, mainly during designing the strategies and evaluation of the undertaken activities.

Keywords: quality of life, childhood, neighborhood, spatial inequalities. 